\title{
Analysis of Teaching Materials in Learning Evaluation for Performance Assessment Based on National Standard University
}

\author{
Febiana Wulandari \\ Magister of Chemistry Education: \\ Postgraduate School \\ Universitas Negeri Medan \\ Medan, Indonesia \\ febianawulandari1994@gmail.com
}

\author{
Ajat Sudrajat \\ Departement of Chemistry Education \\ Universitas Negeri Medan \\ Medan, Indonesia
}

\author{
Mahmud \\ Departement of Chemistry Education \\ Universitas Negeri Medan \\ Medan, Indonesia
}

\begin{abstract}
The implementation of the Indonesian National Qualification Framework (KKNI) in higher education curriculum will strengthen the accountability of the implementation of education while ensuring the quality of graduates. The quality of graduates can be seen from the results of learning outcomes that have been obtained by students. Teaching material is one of the learning tools that is influential in the process of obtaining learning outcomes so as to improve the quality of learning in higher education. The evaluation and assessment of learning outcomes course is a course taught at universitas at the bachelor degree level of the education study program. This course includes material on understanding philosophies, concepts, principles and procedures in educational assessment and evaluation. This research was conducted to analyze the existing textbooks so that they get considerations to produce textbooks that are in accordance with the university national standards. This study is also part of the study on development of multimedia based innovative performance assessment teaching materials to improve student learning outcomes of chemistry education study program in Universitas Negeri Medan.
\end{abstract}

Keywords-analysis; KKNI; teaching materials; learning evaluation; performance assessment

\section{INTRODUCTION}

Textbooks are one of the learning tools that are influential in the process of obtaining learning outcomes so as to improve the quality of learning in higher education. Teaching material is very useful to provide experiences and learning resources directly and concretely to students because it can provide illustrations on material that is difficult to hold, visit or see directly [1]. Textbooks are print learning media that contains knowledge of the results of the analysis curriculum in written form [2].

Quality teaching materials must be able to present teaching materials in accordance with curriculum demands, follow the development of science and technology, and be able to bridge learning so that the specified competencies can be achieved [3]. Lecturers as facilitators need to be more creative in developing the learning process, one of which is to innovate in the development of teaching materials, both in terms of technology and the approach adopted to be very important for the achievement of learning objectives [4].

Development of teaching materials is one form of learning process activities to improve or improve the quality of learning that takes place [5]. The development of teaching materials must be based on prerequisites from the competent body namely the National Education Standards Agency (BSNP), and the applicable curriculum. Applicable curriculum is Indonesian National Qualification Framework Curriculum (KKNI). This development is expected to be a trigger for students' enthusiasm to learn so as to improve student learning outcomes. Innovation in developing teaching materials is very necessary so that the teaching materials become more qualified. Learning innovations can be outlined in teaching materials so that the impression of learning is longer remembered by students [6].

Chemistry Learning Evaluation and Evaluation Subjects are educational subjects with complex material content, but they must be finished in one semester and weigh 3 SKS. Because of the limited time and complexity of the Chemistry Learning Evaluation and Evaluation course content that must be taught to students, it is very appropriate and appropriate if innovative teaching materials are made, so that the teaching material created becomes more interactive, interesting, and easily understood by students and can certainly expedite the learning process.

Teachers or prospective teachers are expected to conduct a comprehensive and correct assessment of the process and results of science learning. Comprehensive means that the assessment is carried out covering various aspects of competence. Correct means that the assessment is carried out in accordance with the objectives and principles of the assessment which are objective, validity, reliability, democratic and fair. In line with this at the university, lecturers can form a Lecture Reference Unit (SAP), RPS, choose learning strategies and assessments [7]. Therefore, to achieve optimal learning outcomes, in planning learning programs (for example in developing learning tools and 
learning activities, lecturers must pay attention to the affective characteristics of students and prepare assessment instruments that cover cognitive, affective and psychomotor domains. Performance assessments are included in the psychomotor domain.

The purpose of this study was to determine the feasibility of the material, language, presentation, and layout of the three books different publisher. This study is also part of the Study on Development of Multimedia-Based Innovative Performance Assessment Teaching Materials to Improve Student Learning Outcomes of Chemistry Education Study Program in Universitas Negeri Medan.

\section{METHOD}

Analysis of teaching materials in learning evaluation for performance assessment using research design used is Research and Development (R \& D) model of Borg and Gall. This research is only done in the early stages of the evaluation textbooks. The types of data obtained in this evaluation textbooks analysis are qualitative and quantitative data. Qualitative data are comments, suggestions or criticisms of the evaluation textbooks analyzed. While the quantitative data in the form of numbers obtained based on the validation sheet of the study textbooks using the Likert scale $(4,3,2,1)$ [8]. The data collection instrument used in this research is a validation sheet of evaluation textbook A, B, and C based on SNPT. The data analysis technique used to analyze the validation result data of evaluation textbook is the average calculation technique. The range of validation criteria to the complete calculation results can be observed in TABLE 1 .

TABLE 1. CRITERIA FOR VALIDATION EVALUATION TEXTBOOK

\begin{tabular}{|c|c|}
\hline Average & Variable of Criteria \\
\hline $3,26-4,00$ & very valid and can be used \\
\hline $2,51-3,25$ & valid and can be used \\
\hline $1,76-2,50$ & less valid and revision \\
\hline $1,00-1,75$ & not valid and total revision \\
\hline
\end{tabular}

\section{RESULT AND DISCUSSION}

Before conducting innovative evaluation teaching materials for performance assessment. Researchers conducted an analysis of the learning evaluation textbooks from three different book publishers. The learning evaluation textbooks for performance assessment in the analysis consist of four parts of the feasibility of content, the feasibility of language, the feasibility of presentation and feasibility of graphic. Based on the validation results it is found that the practical guidebook $\mathrm{A}, \mathrm{B}$, and $\mathrm{C}$ can be said to be valid and can be used. Validation results on the practical guidebooks A, B, and $\mathrm{C}$ can be seen in Fig. 1 .

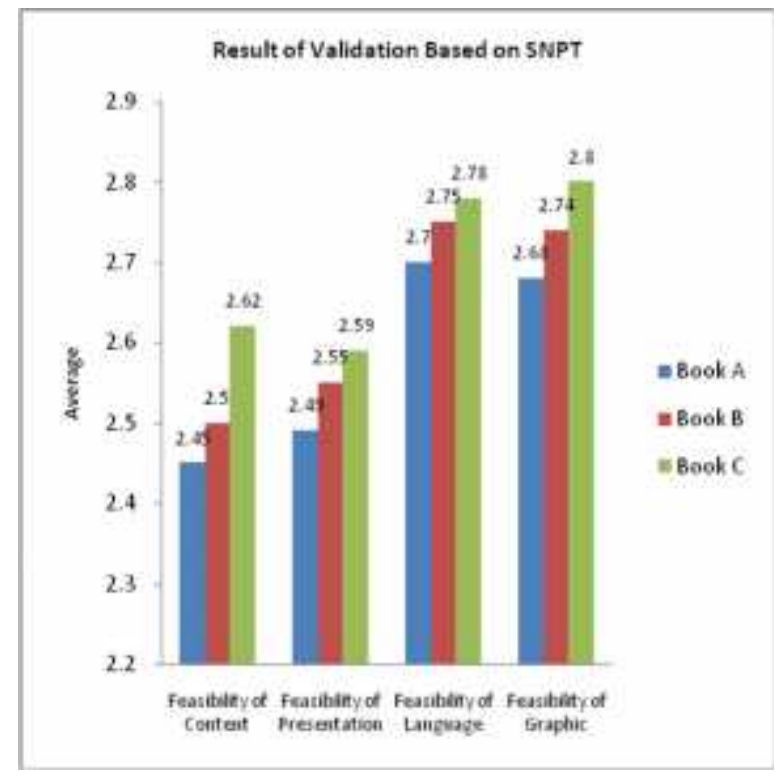

Fig. 1. Result of Validation Based on SNPT

The results of the analysis of the content feasibility state that the study learning evaluation for performance assessment textbooks that has been analyzed has been valid and can be used. But there are still some that must be on the content feasibility of which is the depth of the material needs to be readjusted with teaching materials, sub-material conformity in the practical guide with the concept and the addition of learning objectives in each practical activity. Validation of content feasibility can be seen in Fig. 2.

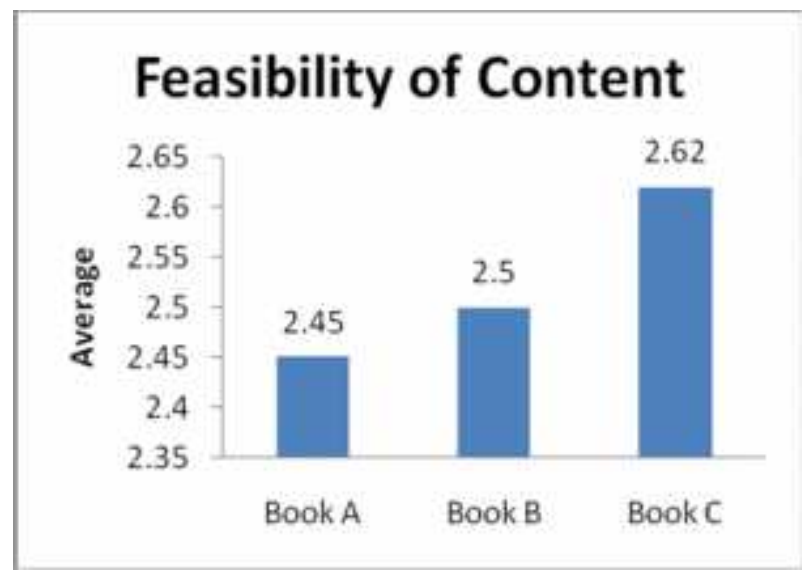

Fig. 2. Result of Validation Feasibility of Content Learning Evaluation for Performance Assessment Textbooks A, B, And C.

The results of the analysis of the language feasibility stated that learning evaluation for performance assessment textbooks analyzed was valid and usable. However, by adjusting the sentence that accompanies an image or illustration to make it look more clear. Validation feasibility of language can be seen in Fig. 3. 


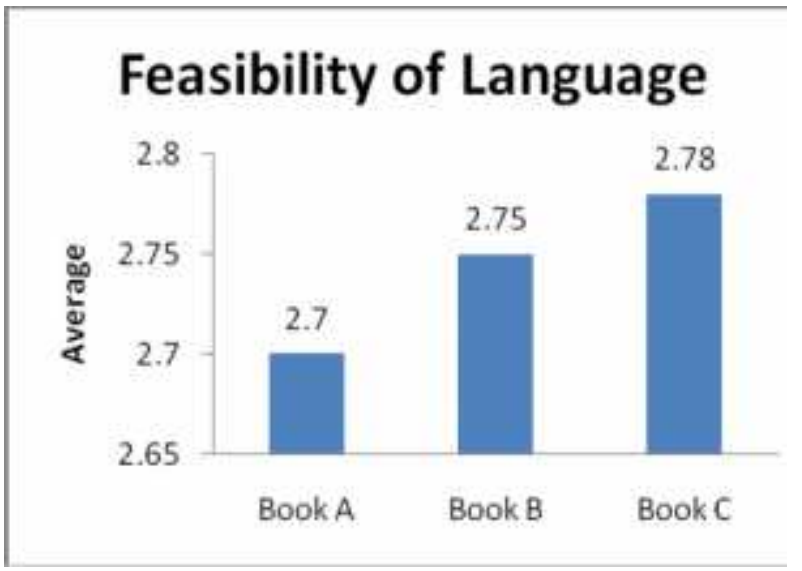

Fig. 3. Result of Validation Feasibility of Language Learning Evaluation for Performance Assessment Textbooks A, B, And C.

The results of the analysis on the feasibility of the presentation stated that the learning evaluation for performance assessment textbooks that was analyzed was valid and could be used. However, by improving the cover design and the overall design of the practicum guide to attracting students' interest. Validation of presentation feasibility can be seen in Fig. 4.

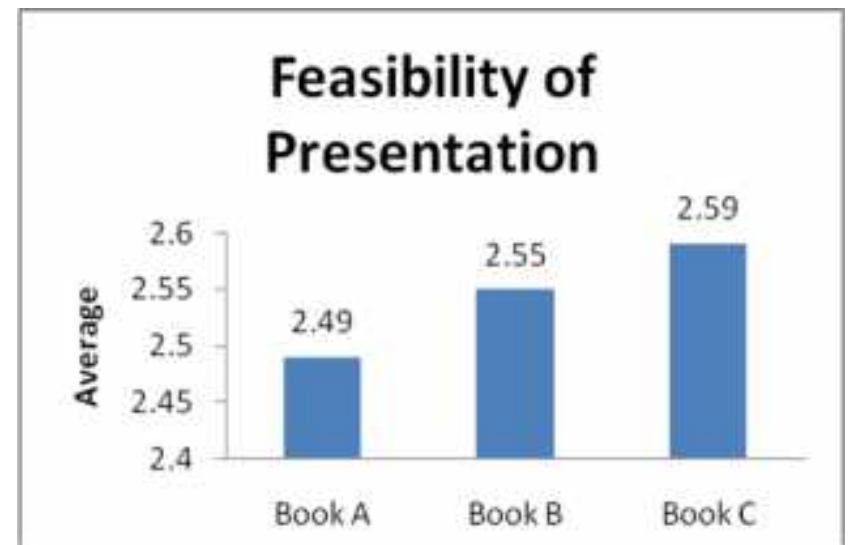

Fig. 4. Result of Validation Feasibility of Presentation Learning Evaluation for Performance Assessment Textbooks A, B, And C.

The results of the analysis on the feasibility of graphic stated that learning evaluation for performance assessment textbooks that has been analyzed has been valid and can be used. However, by improving the size of the book to comply with ISO standards. Validation of the feasibility of graphics can be seen in Fig. 5.

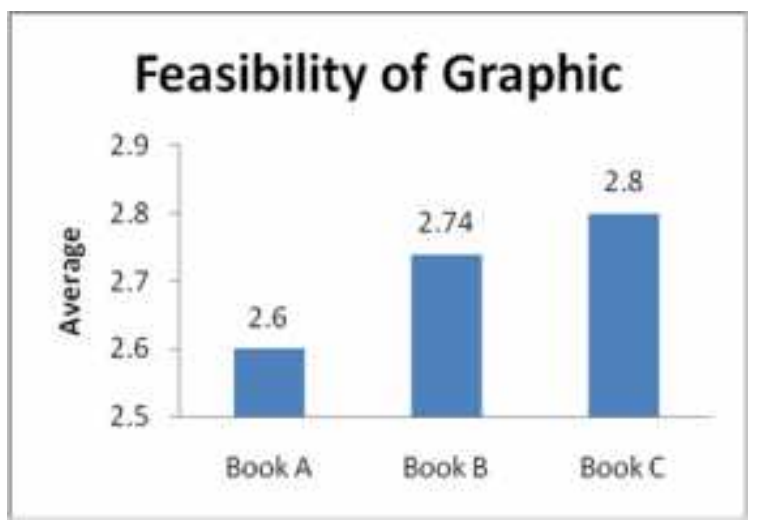

Fig. 5. Result of Validation Feasibility of Graphic Learning Evaluation for Performance Assessment Textbooks A, B, And C.

After obtaining the results of learning evaluation for performance assessment textbooks then further can be done to the development of innovative guidebook in accordance with the Indonesian National Qualification Framework Curriculum (KKNI) . The comparison of the components contained in the innovation guidebook chemistry guide according to the Indonesian National Qualification Framework Curriculum (KKNI) with the learning evaluation for performance assessment analyzed can be seen in TABLE 2 .

TABLE 2. DEVELOPMENT PLAN FOR AN INNOVATIVE LEARNING EVALUATION FOR PERFORMANCE ASSESSMENT BOOK

\begin{tabular}{|c|c|c|c|c|c|}
\hline No & Component & $\begin{array}{c}\text { Book } \\
\text { innovation }\end{array}$ & $\begin{array}{l}\text { Boo } \\
\text { k A }\end{array}$ & $\begin{array}{l}\text { Boo } \\
\text { k B }\end{array}$ & $\begin{array}{l}\text { Boo } \\
\mathrm{k} \mathrm{C}\end{array}$ \\
\hline 1. & Definition of assessment & $\sqrt{ }$ & $\sqrt{ }$ & $\sqrt{ }$ & $\sqrt{ }$ \\
\hline 2. & $\begin{array}{l}\text { Functions and Purpose of } \\
\text { the Assessment }\end{array}$ & $\sqrt{ }$ & $\sqrt{ }$ & $\sqrt{ }$ & $\sqrt{ }$ \\
\hline 3. & Principles of assessment & $\sqrt{ }$ & - & $\sqrt{ }$ & $\sqrt{ }$ \\
\hline 4. & $\begin{array}{l}\text { Methods and Target } \\
\text { Assessment* }\end{array}$ & $\sqrt{ }$ & - & - & - \\
\hline 5. & $\begin{array}{l}\text { Definition of } \\
\text { performance assessment }\end{array}$ & $\sqrt{ }$ & $\sqrt{ }$ & $\sqrt{ }$ & $\sqrt{ }$ \\
\hline 6. & $\begin{array}{l}\text { Component of } \\
\text { performance assessment }\end{array}$ & $\sqrt{ }$ & $\sqrt{ }$ & $\sqrt{ }$ & $\sqrt{ }$ \\
\hline 7. & $\begin{array}{l}\text { Criteria and } \\
\text { Characteristics of } \\
\text { Performance } \\
\text { Assessment* }\end{array}$ & $\sqrt{ }$ & - & - & - \\
\hline 8. & $\begin{array}{l}\text { The steps to make a } \\
\text { performance assessment } \\
\text { instrument* }\end{array}$ & $\sqrt{ }$ & - & - & $\sqrt{ }$ \\
\hline 9. & $\begin{array}{l}\text { Implementation of } \\
\text { performance } \\
\text { assessments* }\end{array}$ & $\sqrt{ }$ & - & - & - \\
\hline 10. & $\begin{array}{l}\text { Performance assessment } \\
\text { assessment techniques }\end{array}$ & $\sqrt{ }$ & - & $\sqrt{ }$ & $\sqrt{ }$ \\
\hline 11. & $\begin{array}{l}\text { Strengths and } \\
\text { weaknesses of } \\
\text { performance assessment* }\end{array}$ & $\sqrt{ }$ & - & - & $\sqrt{ }$ \\
\hline 12. & $\begin{array}{l}\text { Constraints on the } \\
\text { performance assessment* }\end{array}$ & $\sqrt{ }$ & - & - & - \\
\hline 13. & $\begin{array}{l}\text { Examples of performance } \\
\text { assessment instruments } \\
\text { in learning chemistry* }\end{array}$ & $\sqrt{ }$ & - & - & - \\
\hline
\end{tabular}

Description: $*=$ innovation contained in the book 
The innovative learning evaluation for performance assessment book contain several components including, methods and target assessment, criteria and characteristics of performance assessment, the steps to make a performance assessment instrument, implementation of performance assessments, strengths and weaknesses of performance assessment, constraints on the performance assessment, examples of performance assessment instruments in learning chemistry and analysis curriculum.

\section{CONCLUSION}

Learning evaluation for performance assessment textbooks analyzed consisted of four parts namely the feasibility of content, the feasibility of language, the feasibility of presentation and feasibility of graphic. Based on the above discussion, the book that has been analyzed has been feasible to be used but there are still some things that must be developed considering the guidebook that is analyzed still explaining the material about the performance assessment briefly and not yet deeply. the results of this analysis will be used to develop textbooks created in the form of digital books with learning evaluation materials, especially on performance assessment materials that are in accordance with the SNPT and KKNI.

\section{REFERENCES}

[1] Folb, B.L., Wessel, C.B., \& Czechowski, L.J. Clinical and Academic Use of Electronic and Print Book, The Health Sciences Library System E-Book Study at University of Pittsburgh, Journal of the Medical Library Association: JMLA, 99(3): 218-228, 2011.

[2] Habibi, Endang., Mohammad. Pengembangan Buku Ajar Mata kuliahMikrobiologi Dasar. Jurnal Pendidikan: Teori, Penelitian, Pengembangan, 5(1): 2502- 471X, 2016.

[3] Situmorang, M. Pengembangan Buku Ajar Kimia SMA Melalui Inovasi Pembelajaran dan Integrasi Pendidikan Karakter Untuk Meningkatkan Hasil Belajar Siswa, Prosiding Seminar dan Rapat Tahunan BKS PTN-B Bidang MIPA di Bandar Lampung, Tgl 10-12 Mei 2013, pp. 237-246, 2013
[4] E Fitriani, H., Situmorang, M., \& Darmana, A. Pengembangan Bahan Ajar Inovatif Dan Interaktif Melalui Pendekatan Sainstifik Pada Pengajaran Larutan Dan Koloid. Jurnal Edukasi Kimia, 2(1), 48-53, 2017.

[5] Trisnaningsih. Pengembangan Bahan Ajar Untuk Meningkatkan Pemahaman Materi Mata Kuliah Demografi Teknik, Jurnal Ekonomi dan Pendidikan 4(2):1-13, 2007.

[6] Tompkins, C.J., Rosen, A.L., dan Larkin, H. Guest Editorial: An Analysis of Social Work Textbooks for Aging Content: How Well do Social Work Foundation Texts Prepare Students for Our Aging Society? Journal of Social Work Education 42(1): 3-24, 2006.

[7] Sudrajat, A, et.al. Pengembangan Perangkat Penilaian Psikomotor.Jurnal Chemica, 12(1): 1-8, 2011.

[8] Arikunto, S., Prosedur Penelitian Suatu Pendekatan Praktik. Jakarta: PT. Rineka Cipta, 2010. 